\begin{tabular}{|c|c|}
\hline Title & Synthesis of tunicaminyluracil derivatives. \\
\hline Author(s) & Ichikawa, Satoshi; Matsuda, A kira \\
\hline Citation & $\begin{array}{l}\text { Nucleosides, nucleotides \& nucleic acids, 23(1-2), 239-253 } \\
\text { https://doi.org/10.1081/NCN-120027831 }\end{array}$ \\
\hline Issue Date & 2004 \\
\hline Doc URL & http:/hdl.handle.net/2115/46948 \\
\hline Rights & $\begin{array}{l}\text { This is an electronic version of an article published in Nucleosides, Nucleotides \& Nucleic A cids, } 23(1 / 2), 239-253 \text {, } \\
\text { 2004. Nucleosides, Nucleotides \& Nucleic A cids is available online at: } \\
\text { http:/www.informaworld.com/openurl ?genre=article\& issn=15257770\&volume=23\&issue=1/2\& spage=239 }\end{array}$ \\
\hline Type & article \\
\hline File Information & 330NucNucNucA cid.pdf \\
\hline
\end{tabular}

Instructions for use 


\title{
SYNTHESIS OF TUNICAMINYLURACIL DERIVATIVES ${ }^{\dagger}$
}

\author{
Satoshi Ichikawa and Akira Matsuda* \\ Graduate School of Pharmaceutical Sciences, Hokkaido University, \\ Kita-12, Nishi-6, Kita-ku, Sapporo 060-0812, Japan
}

Running title: tumicamycins, tunicaminyluracil, antibiotics, samarium diiodide, aldol reaction, Pummerer reaction

$\dagger$ In honor and celebration of the $70^{\text {th }}$ birthday of Professor Leroy B. Townsend

*Author to whom reprint requests should be addressed.

Phone: +81-11-706-3228. Fax: +81-11-706-4980.

E-mail: matuda@pharm.hokudai.ac.jp

Phone: +81-11-706-3230. Fax: +81-11-706-4980.

E-mail: ichikawa@pharm.hokudai.ac.jp

This paper constitutes Part 225 of Nucleosides and Nucleotides: Shuto, S.; Fukuoka, M.; Kudoh, T.; Garnham, C.; Galione, A.; Potter, B. V. L.; Matsuda, A. J. Med. Chem. 2003, in press.

\begin{abstract}
A tunicaminyluracil derivative, which is a key component of the tunicamycin nucleoside antibiotics, was synthesized using a samarium diiodide $\left(\mathrm{SmI}_{2}\right)$ mediated aldol reaction and intramolecular Pummerer reaction as the key steps. The $\alpha$-phenylthio ketone 11, the precursor of the samarium enolate, was prepared from D-galactose. Treatment of $\mathbf{1 1}$ with $\mathrm{SmI}_{2}$ at $-40{ }^{\circ} \mathrm{C}$ resulted in complete conversion to the corresponding samarium enolate, and subsequent addition of uridine 5'-
\end{abstract}


aldehyde 12 afforded the desired aldol products 13a,b. Compound 13a was converted to the sulfoxide 15 by a sequential diastereoselective reduction of the ketone and an oxidation with $m$ CPBA. Activation of 15 with $\mathrm{Tf}_{2} \mathrm{O}$ provided the desired cyclized compound 17 . In this reaction, the aldol product $\mathbf{1 3 a}$ was also obtained as a consequence of a competitive intramolecular version of DMSO-oxidation via a 7membered ring intermediate. Compound $\mathbf{1 8}$ or $\mathbf{1 9}$ are ready for use as a glycosyl donor in glycosylations to provide a range of analogues as potential glycosyltransferase inhibitors as well as related natural products.

\section{Introduction.}

Tunicamycins $^{1-3}(\mathbf{1}$, Figure 1), isolated from the fermentation broths of Streptomces lysosuperficus in 1971, are nucleoside antibiotics composed of uridine, $N$-acetylglucosamine (GlcNAc), an aminoundecose which is a unique higher carbon sugar called tunicamine, and an amide-linked fatty acyl side chain. ${ }^{2}$ They exhibit a variety of biological properties including antibacterial, antiviral, antifungal, and antitumor activities. ${ }^{4,5}$ Treatment of eukaryotic cells with tunicamycins results in the complete truncation of the oligosaccharides from $N$-linked glycopeptides. Therefore, tunicamycins are also utilized as a biological tool to reveal functions of the oligosaccharides in the $N$-linked glycopeptides. Tunicamycins strongly and reversibly inhibits UDP-GlcNAc:polyprenol phosphate GlcNAc-1-P translocase, the enzyme which is responsible for the first $N$-acetylglucosamination of the $N$-linked glycopeptide in endothelial reticulum (ER). It is suggested that the structure of tunicamycins closely resemble the transition state of the transfer reaction of UDP-GlcNAc onto a dolicol monophosphate in the ER membrane catalyzed by the translocase (Figure 1). In particular, the C7'C11' moiety of the tunicamycin structure forming a galactopyranoside can be considered as a mimic of the structure of a divalent metal chelated diphosphate. This structural mimicry has been utilized to design inhibitors of glycosyltransferases, which are responsible for oligosaccharide biosynthesis. ${ }^{6}$ Thus, 
tunicaminyluracil (2), which lacks the GlcNAc moiety and the fatty acyl chain of the tunicamycins, would be expected to be a versatile synthetic intermediate for the synthesis of various glycosyltransferase inhibitors. ${ }^{7}$

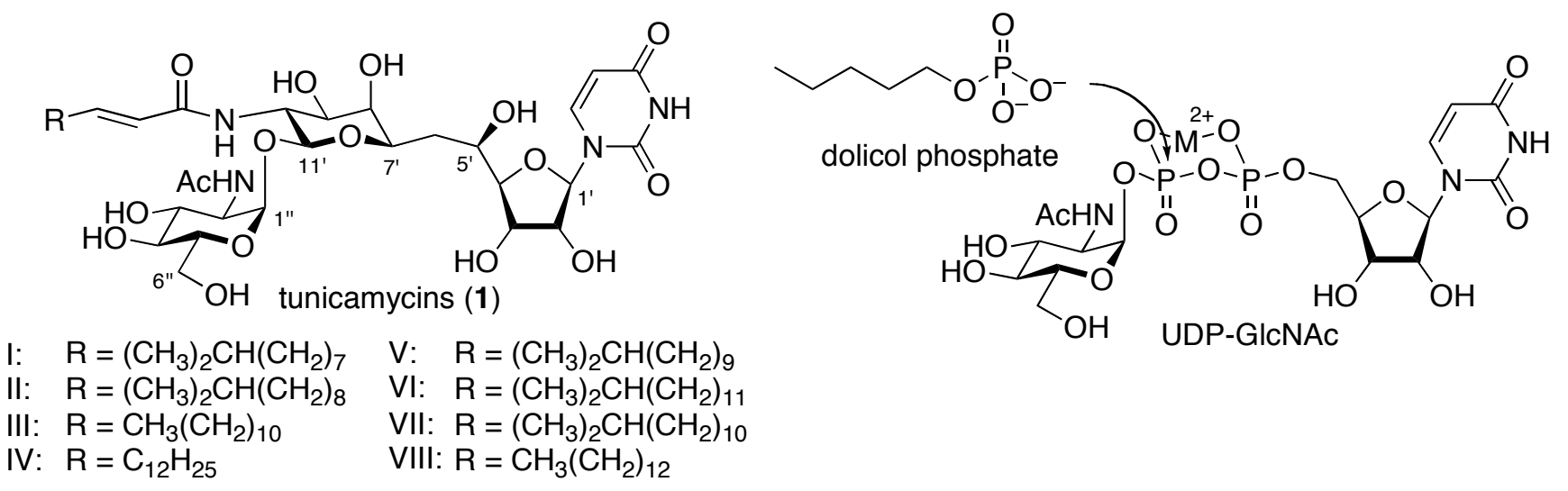

Figure 1. Structure of tunicamycins (1) and UDP-NAcGlc

Their structural complexity also renders them worthy targets in organic synthesis. The total synthesis of tunicamycins has been accomplished by the groups of Suami's ${ }^{8}$ and Myers ${ }^{9}$, and other synthetic studies of related compounds have also been reported. ${ }^{10}$

Previously, we applied the samarium diiodide $\left(\mathrm{SmI}_{2}\right)$ mediated $\mathrm{C}-\mathrm{C}$ bond formation reaction to nucleoside chemistry ${ }^{11}$ and developed a novel aldol reaction via the samarium enolate (B) generated by two electron reductions of the $\alpha$-phenylthio ketone (A) (Scheme 1). ${ }^{12}$ The neutral and mild reaction conditions and the reactivity of the regioselectively generated samarium enolate $(\mathbf{B})$ are suitable for the carbon-chain elongation to a base-labile nucleoside 5'-aldehyde derivative. This reaction was successfully applied to the total synthesis of the nucleoside antibiotic, herbicidin $\mathrm{B} \cdot{ }^{13} \mathrm{This} \mathrm{SmI}_{2}$ mediated aldol reaction could also be applied to the synthesis of tunicaminyluracil (2), the structure of which is a 5'-carbon-branched uridine derivative. Here we describe the synthesis of tunicaminyluracil (2) as an extension of our $\mathrm{SmI}_{2}$-mediated aldol reaction. 
Scheme 1. Samarium diiodide $\left(\mathrm{Sml}_{2}\right)$-mediated aldol reaction

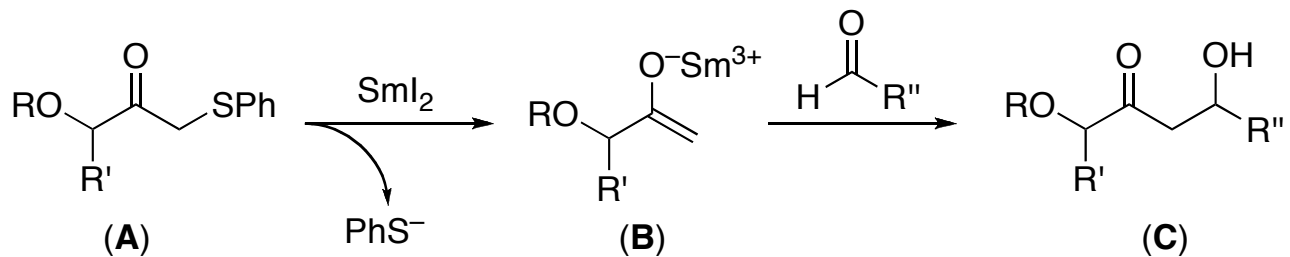

Scheme 2. Retro-synthetic analysis of tunicaminyluracil

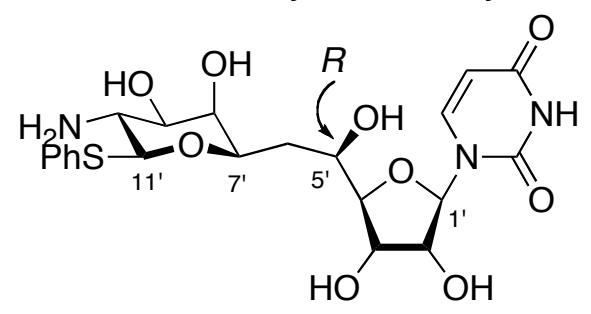

tunicaminyluracil (2) intramolecular Pummerer reaction

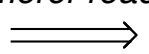<smiles>N[C@@H](Cc1ccccc1)[C@H](O)[C@H](O)[C@H](O)C[C@H](O)[C@H]1O[C@@H](n2ccc(=O)[nH]c2=O)[C@H](O)C1O</smiles>

(D)

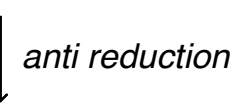<smiles>N[C@@H](CSc1ccccc1)[C@H](O)[C@H](O)[C@H](O)C(=O)C[SbH2]c1ccccc1</smiles>

Our strategy includes the regioselective generation of a samarium enolate from the $\alpha$-phenylthio ketone $(\mathbf{G})$, aldol reaction with the uridine 5'-aldehyde $(\mathbf{F})$ to assemble the undecose system $(\mathbf{E})$. After stereoselective reduction of the 7'-keto group in $\mathbf{E}$, cyclization of the resulting 7'-hydroxyl group in $\mathbf{D}$ to the carbon atom at the 11 '-position by an intramolecular Pummerer reaction can be expected to give 2. If such a cyclization occurs effectively, further introduction of certain carbohydrates using the resulting phenylthio pyranoside $\mathbf{2}$ as a versatile intermediate could be realized. Therefore, this approach would provide a ready access to a range of sugar analogues for the development of glycosyltransferase inhibitors.

\section{Results and Discussion.}


The synthesis of the key $\alpha$-phenylthio ketone 11 is summarized in Scheme 3. Protection of 2-azido2-deoxy-3,4,6-tri- $O$-acetylgalactose $\mathbf{3}^{14}$ with a TBDPS group gave only the $\beta$-galactoside $\mathbf{4}$, and successive removal of the acetyl groups followed by protection of the resulting secondary alcohols with an isopropylidene group under thermodynamic conditions provided 5. Introduction of a phenylthio group at the 6-position, which would become a leaving group when the samarium enolate is generated, was conducted by activation of the hydroxyl group as its triflate, followed by displacement with thiophenol to afford $\mathbf{6}$ in $93 \%$ yield in 2 steps. After deprotection of the TBDPS group of $\mathbf{6}$ with tetrabutylammonium fluoride (TBAF), followed by reductive ring opening of the resulting pyranose by $\mathrm{NaBH}_{4}$, the desired diol 7 was obtained in $86 \%$ yield. Subsequent protecting group manipulations afforded the mono-benzoate $\mathbf{8}$ ( $83 \%$ yield for 3 steps) at the 5 position, and the remaining primary alcohol at position 1 was further converted to a phenylthio group in $90 \%$ yield as in the procedure for the preparation of $\mathbf{6}$. It should be noted that selective activation of the primary alcohol of 7 with $\mathrm{Tf}_{2} \mathrm{O}$ followed by substitution with thiophenol was unsuccessful and gave a tetrahydropyran derivative as a

Scheme $3^{*}$. Preparation of $\alpha$-phenylthio ketone

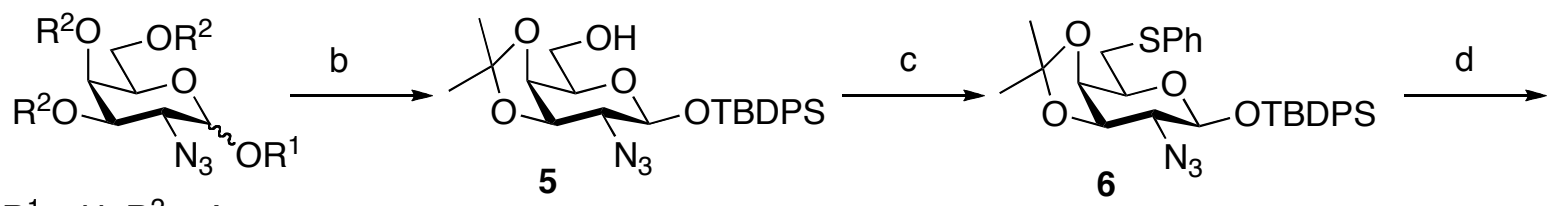

3, $R^{1}=H, R^{2}=A c$

4, $R^{1}=$ TBDPS $(\beta$-anomer $) \longleftarrow a$

$R^{2}=A c$

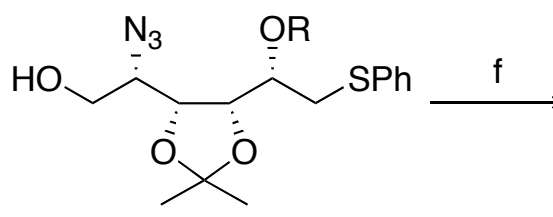

7, $\mathrm{R}=\mathrm{H}$

$8, R=B z$

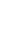

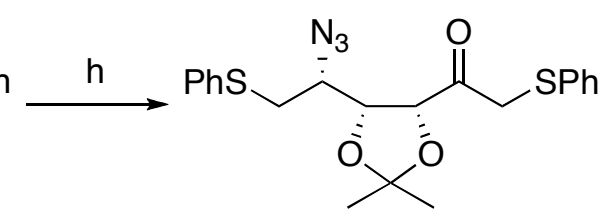

11

"Reagents and conditions; a. TBDPSCl, imidazole, DMF, 73\%. b. i) $\mathrm{NaOMe,} \mathrm{MeOH}$. ii) 2,2'dimethoxypropane, $p$ - $\mathrm{TsOH}$, acetone, $69 \%$ for 2 steps. c. i) $\mathrm{Tf}_{2} \mathrm{O}$, pyridine, $\mathrm{CH}_{2} \mathrm{Cl}_{2}$. ii) $\mathrm{PhSH}, \mathrm{Et}_{3} \mathrm{~N}, \mathrm{CH}_{2} \mathrm{Cl}_{2}$ $93 \%$ for 2 steps. d. i) TBAF, THF. ii) $\mathrm{NaBH}_{4}, \mathrm{MeOH}, 86 \%$ for 2 steps. e. i) TBSCl, imidazole, DMF. ii) $\mathrm{BzCl}$, pyridine. iii) TBAF, THF, $83 \%$ for 3 steps. f. i) $\mathrm{Tf}_{2} \mathrm{O}$, pyridine, $\mathrm{CH}_{2} \mathrm{Cl}_{2}$. ii) $\mathrm{PhSH}, \mathrm{Et}_{3} \mathrm{~N}, \mathrm{CH}_{2} \mathrm{Cl}_{2} 90 \%$ for 2 steps. g. $\mathrm{NaOMe}, \mathrm{MeOH}, 90 \%$.h. Dess-Martin periodinane, $\mathrm{CH}_{2} \mathrm{Cl}_{2}, 99 \%$. 
result of ring closure of the triflate intermediate. Deprotection of the benzoyl group followed by DessMartin periodinane oxidation afforded the $\alpha$-phenylthio ketone $\mathbf{1 1}$ without oxidizing either of the phenylthio groups in quantitative yield.

The key $\mathrm{SmI}_{2}$-mediated aldol reaction was conducted (Scheme 4) and the results are summarized in Table 1. Our previous study revealed that the two-electron reduction by $\mathrm{SmI}_{2}$ to generate a samarium enolate from a 1-phenylthio-2-ulose derivative occurred at $-78{ }^{\circ} \mathrm{C}$. However, the treatment of $\alpha$ phenylthio ketone 11 with 2.2 equiv of $\mathrm{SmI}_{2}$ followed by addition of 1.0 equiv of the aldehyde $\mathbf{1 2}^{15}$ at $78^{\circ} \mathrm{C}$ gave the desired aldol products $\mathbf{1 3 a}, \mathbf{b}$ in $13 \%$ yield (Table 1 , entry $1,5^{\prime} R / 5^{\prime} S=64 / 36$ ). The low yield of the products and the large amount of the unreacted $\mathbf{1 1}$ observed in the reaction mixture indicated that the $\alpha$-phenylthio ketone $\mathbf{1 1}$ without a hetero atom adjacent to the phenylthio group is less reactive to the two-electron reduction than that with an oxygen atom. ${ }^{12,13}$ After several attempts to optimize the reaction temperature, the reaction at $-40{ }^{\circ} \mathrm{C}$ gave complete consumption of 11. Addition of the aldehyde $\mathbf{1 2}$ at $-78{ }^{\circ} \mathrm{C}$ after generation of the samarium enolate provided 13a,b in $71 \%$ (entry 3 , $\left.5^{\prime} R / 5^{\prime} S=66 / 34\right)$, although the addition at $0{ }^{\circ} \mathrm{C}$ resulted in inverted selectivity (entry 2, $\left.5^{\prime} R / 5^{\prime} S=28 / 72\right)$. It is known that $\mathrm{SmI}_{2}$ can reduce an azido group to the corresponding amino group. However, no such reduction of the azido group in $\mathbf{1 3}$ was detected, and therefore the two-electron Scheme 4. $\mathrm{Sml}_{2}$-mediated aldol reaction
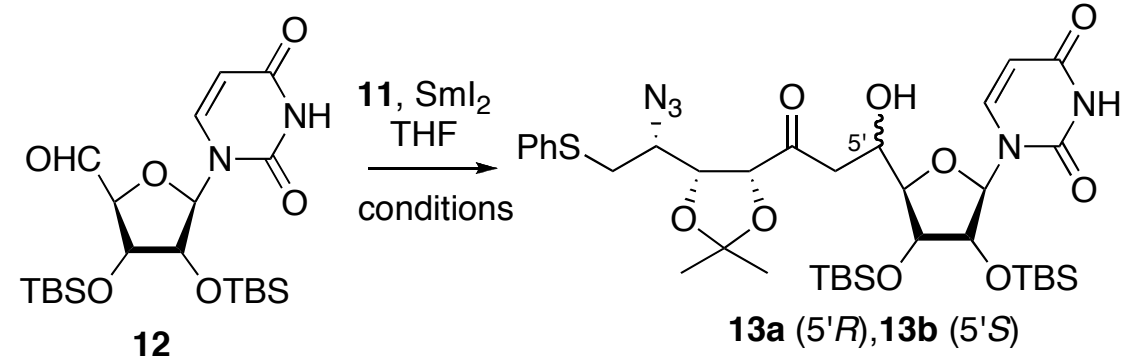

Table 1

\begin{tabular}{crrccc} 
& \multicolumn{2}{c}{ temp. $\left({ }^{\circ} \mathrm{C}\right)^{\star}$} & & \\
\cline { 2 - 3 } entry & A & $\mathrm{B}$ & & yield $(\%)$ & ratio (13a/13b) \\
\hline 1 & -78 & -78 & 13 & $64 / 36$ \\
2 & -40 & 0 & 62 & $28 / 72$ \\
3 & -40 & -78 & 71 & $66 / 34$ \\
\hline
\end{tabular}

${ }^{*} \mathrm{~A}$ : temperature at the addition of $\mathbf{1 1}$ $\mathrm{B}$ : temperature at the addition of 12 
chemoselectively accomplished.

Stereoselective reduction of the ketone 13a was required in the next step. Intramolecular hydride delivery from $\mathrm{NaBH}(\mathrm{OAc})_{3}$ via a 6-membered transition state selectively afforded the desired 1,3-antidiol 14 in quantitative yield. If the resulting hydroxyl group at the 7' position cyclized with the carbon atom at the 11 position to form a hexopyranose via an intramolecular Pummerer reaction, the desired tunicaminyluracil derivative $\mathbf{1 7}$ could be obtained. There are several methods available to promote the Pummerer reaction including the direct activation of a sulfide or of the corresponding sulfoxide. ${ }^{17}$

Scheme $5^{\star}$. Synthesis of tunicaminyluracil derivative

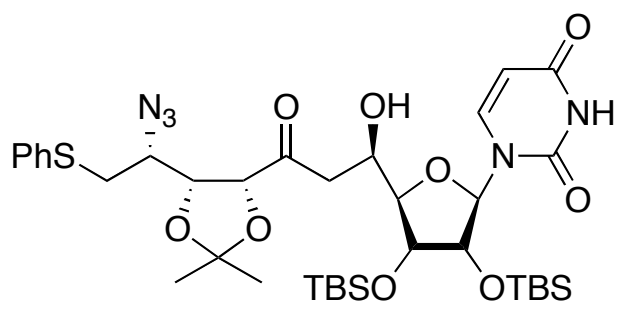

$13 a$

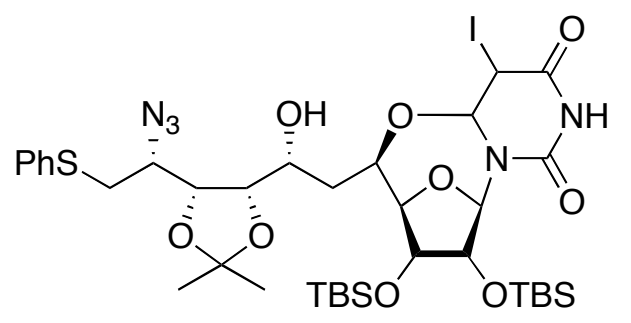

16

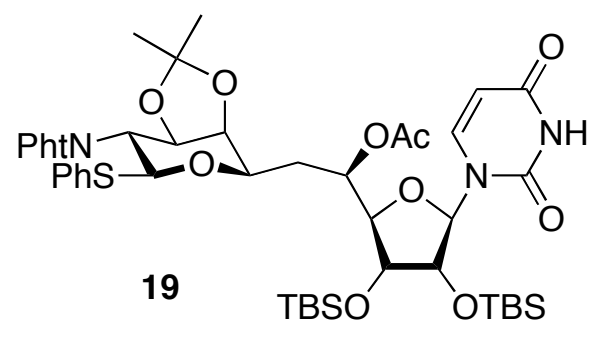
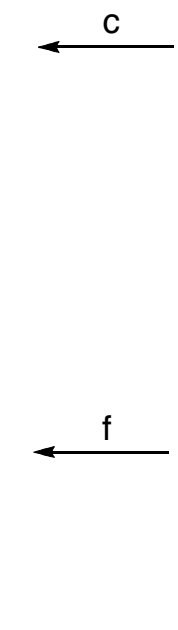
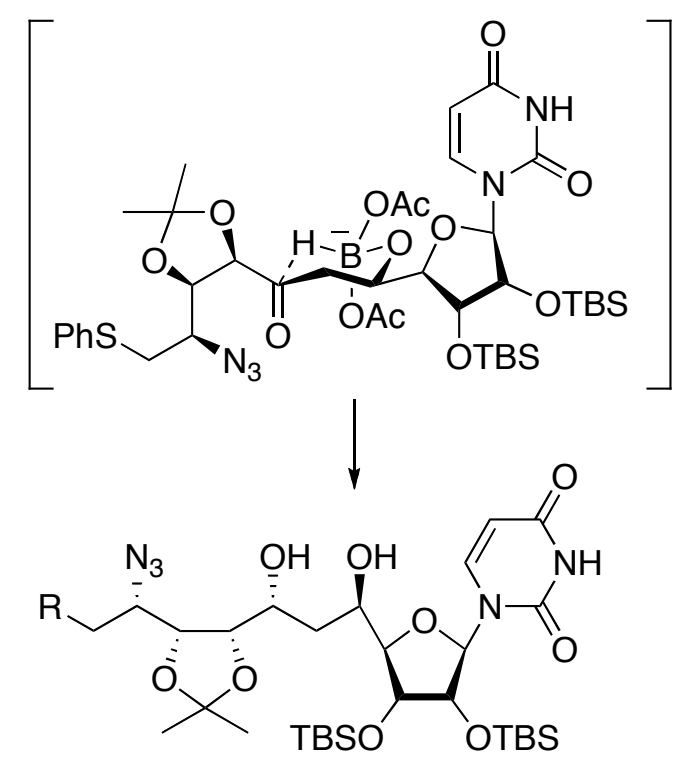

14, $R=P h S \longrightarrow b$
$15, R=P h S(O) \longleftarrow b$

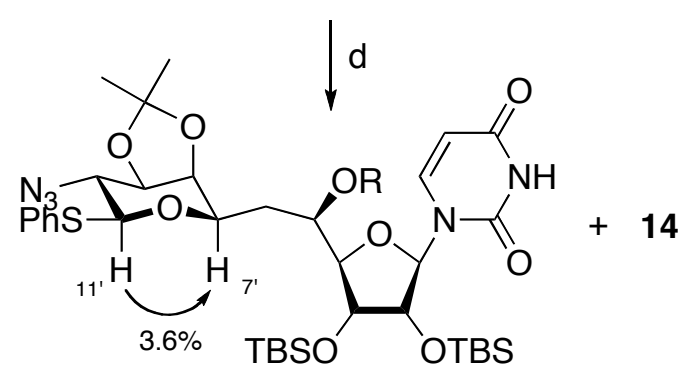

$17, \mathrm{R}=\mathrm{H}$
$18, \mathrm{R}=\mathrm{AC}$

"Reagents and conditions; a. $\mathrm{NaBH}_{4}, \mathrm{AcOH}-\mathrm{CH}_{2} \mathrm{Cl}_{2}, 92 \%$. b. $m \mathrm{CPBA}, \mathrm{CH}_{2} \mathrm{Cl}_{2}, 96 \%$. c. with 14. NIS, TfOH, $\mathrm{CH}_{2} \mathrm{Cl}_{2}$. d. i) $\mathrm{Tf}_{2} \mathrm{O}$, pyridine, $\mathrm{CH}_{2} \mathrm{Cl}_{2}$. ii) $\mathrm{NaBH}_{4}, \mathrm{AcOH}-\mathrm{CH}_{2} \mathrm{Cl}_{2}, 53 \%$ for 17, 36\% for 14 . e. $\mathrm{Ac}_{2} \mathrm{O}, \mathrm{DMAP}, \mathrm{CH}_{2} \mathrm{Cl}_{2}, 96 \%$. f. i) $\mathrm{PhSeH}, \mathrm{Et}_{3} \mathrm{~N}$. ii) phthaloyl dichloride, DBU, toluene, $92 \%$ for 2 steps. 
Direct activation of the sulfide $\mathbf{1 4}$ by treatment with NIS in the presence of a catalytic amount of TfOH resulted in the iodo-etherification product 16 between the 5'-hydroxyl group and the 5,6-double bond within the uracil base, and the desired cyclization failed to occur. Next, the activation of the corresponding sulfoxide 15 was examined. ${ }^{16}$ Oxidation of 14 with $m$ CPBA provided the corresponding sulfoxide $\mathbf{1 5}$ as a mixture of diastereomers. An initial effort to activate 15 with $\left(\mathrm{CF}_{3} \mathrm{CO}\right)_{2} \mathrm{O}$ resulted in extensive trifluoroacetylation of the alcohols and only a trace amount of the desired product $\mathbf{1 7}$ was obtained. However, treatment of the sulfoxide 15 with $\mathrm{Tf}_{2} \mathrm{O}$ in the presence of pyridine at $-20{ }^{\circ} \mathrm{C}$ provided the desired product $\mathbf{1 7}$ along with 13a as an inseparable mixture in a ratio of 62:38. After the mixture was treated with $\mathrm{NaBH}(\mathrm{OAc})_{3}$, compound 17 could be separated from the corresponding reduced product 14 by the usual silica gel column chromatography. The phenylthio glycoside $\mathbf{1 7}$ was a single $\beta$-anomer. The stereochemistry of $\mathbf{1 7}$ was determined by an NOE (3.6\%) between H7' and H11'.

Sulfonylation of the sulfoxide with $\mathrm{Tf}_{2} \mathrm{O}$ promotes $\beta$-elimination to give a thiocarbenium intermediate. Intramolecular nucleophilic attack of the 7'-hydroxyl group on the 11'-carbon atom affords the cyclized product $\mathbf{1 7}$ (Scheme 6, path a). We suppose that the aldol product 13a is produced through the nucleophilic attack of the 7'-hydroxyl group on the activated thionium cation with the formation of a 7-membered ring followed by hydrogen abstraction and elimination resulting in the oxidation of the alcohol, an intramolecular version of the DMSO-oxidation (Scheme 6, path b). The fact that the 5'-keto derivative or the sulfoxide of $\mathbf{1 3 a}$, which is also possible a product if this reaction proceeds in an intermolecular fashion, was not detected in the reaction mixture indicates that the mechanism of the oxidation involves the intramolecular pathway b. Following acetylation of the 5'hydroxyl group of $\mathbf{1 7}$, the 10 '-azido group of the corresponding acetate $\mathbf{1 8}$ was reduced with $\mathrm{PhSeH}$ in the presence of $\mathrm{Et}_{3} \mathrm{~N}$. The liberated amine was then protected with a phthaloyl group to afford 19, a fully protected tunicaminyluracil. 


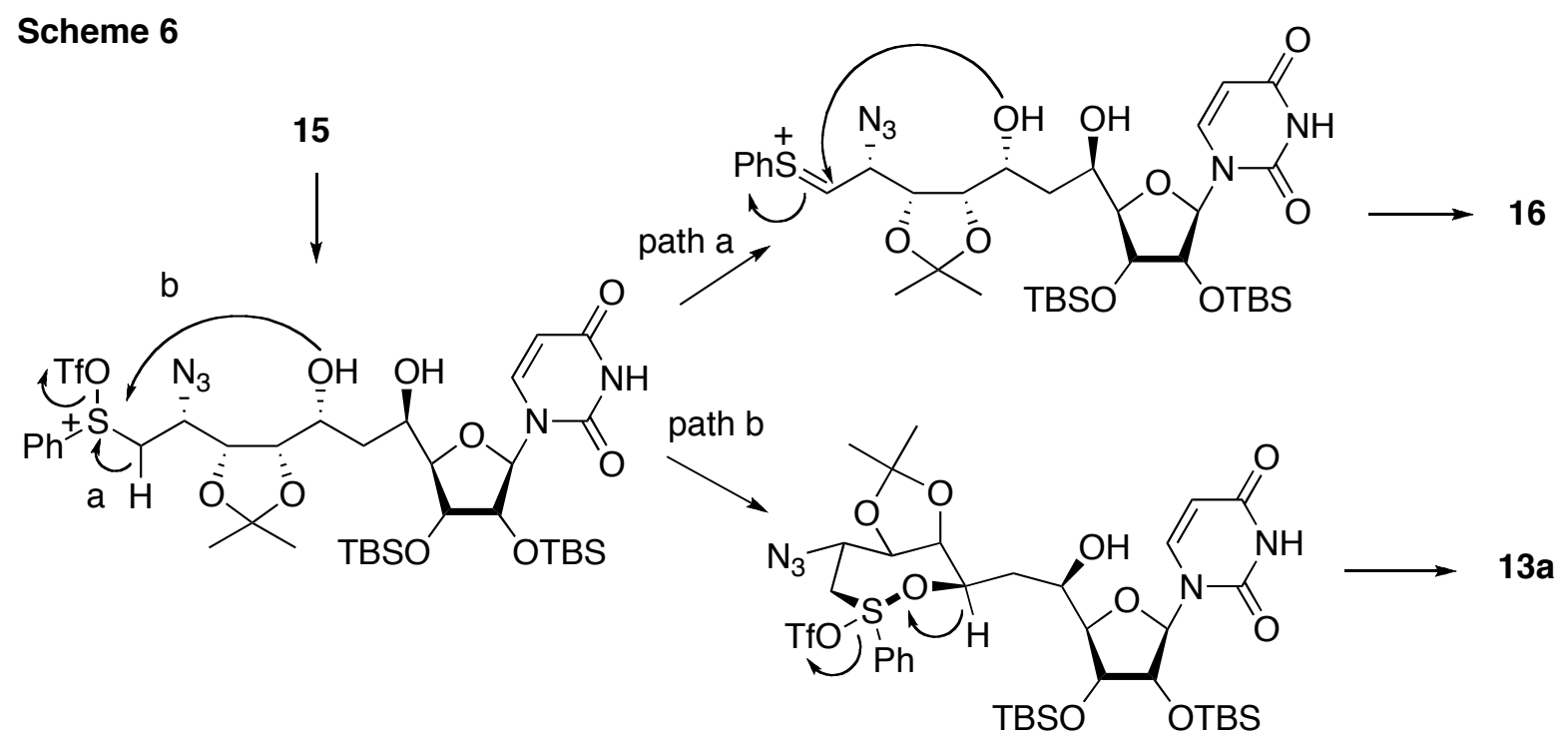

In conclusion, the tumicaminyluracil derivative $\mathbf{1 9}$ has been synthesized by an aldol reaction via the samarium enolate generated from the $\alpha$-phenylthio ketone $\mathbf{1 1}$ and the intramolecular Pummerer reaction as the key steps. The $\mathrm{SmI}_{2}$-mediated aldol reaction was successfully applied to the carbonchain elongation of the uridine 5'-aldehyde derivative 12. Compound $\mathbf{1 8}$ or $\mathbf{1 9}$ would then be ready for use as glycosyl donor in glycosylations to provide a range of sugar analogues as well as related natural products.

\section{Experimental Section:}

General Methods. Physical data were measured as follows: ${ }^{1} \mathrm{H}$ and ${ }^{13} \mathrm{C}$ NMR spectra were recorded at $500 \mathrm{MHz}$ and $125 \mathrm{MHz}$ instruments in $\mathrm{CDCl}_{3}$ as the solvent with tetramethylsilane as an internal standard. Chemical shifts are reported in parts per million $(\delta)$, and signals are expressed as s (singlet), d (doublet), t (triplet), q (quartet), m (multiplet), or br (broad). All exchangeable protons were detected by addition of $\mathrm{D}_{2} \mathrm{O}$. Assignment of ${ }^{1} \mathrm{H}$ signals was based on two-dimentional NMR and NOE experiments. Mass spectra were measured on JEOL JMS-D300 spectrometer. TLC was done on Merck Kieselgel F254 precoated plates. Silica gel used for column chromatography was Merck silica gel 5715. 
of $3(2.50 \mathrm{~g}, 7.50 \mathrm{mmol})$, TBDPSCl (2.34 mL, $9.00 \mathrm{mmol})$, and imidazole $(1.23 \mathrm{~g}, 18.0 \mathrm{mmol})$ in DMF $(40 \mathrm{~mL})$ was stirred for $3 \mathrm{~h}$ at $50{ }^{\circ} \mathrm{C}$. After $\mathrm{MeOH}(5 \mathrm{~mL})$ was added, the mixture was partitioned between AcOEt $(200 \mathrm{~mL})$ and $\mathrm{H}_{2} \mathrm{O}(200 \mathrm{~mL})$, and the organic layer was washed with $\mathrm{H}_{2} \mathrm{O}(200 \mathrm{~mL})$, brine $(100 \mathrm{~mL})$, dried $\left(\mathrm{Na}_{2} \mathrm{SO}_{4}\right)$, and evaporated under reduced pressure. The residue was purified by column chromatography $\left(\mathrm{SiO}_{2}, 25 \% \mathrm{AcOEt} /\right.$ hexane $)$ to give 4 (3.10 g, $73 \%$ as a colorless syrup): $[\alpha]_{\mathrm{D}}-$ $9.29^{\circ}\left(c\right.$ 0.96, $\left.\mathrm{CHCl}_{3}\right) ;{ }^{1} \mathrm{H} \mathrm{NMR}\left(\mathrm{CDCl}_{3}, 500 \mathrm{MHz}\right) \delta 7.73-7.36(\mathrm{~m}, 10 \mathrm{H}), 5.23(\mathrm{~d}, 1 \mathrm{H}, J=3.0 \mathrm{~Hz})$, $3.68(\mathrm{dd}, 1 \mathrm{H}, J=3.3,10.8 \mathrm{~Hz}), 4.46(\mathrm{~d}, 1 \mathrm{H}, J=7.7 \mathrm{~Hz}), 3.96(\mathrm{dd}, 1 \mathrm{H}, J=6.6,11.2 \mathrm{~Hz}), 3.89(\mathrm{dd}, 1 \mathrm{H}$, $J=6.6,11.2 \mathrm{~Hz}), 3.72(\mathrm{dd}, 1 \mathrm{H}, J=7.6,10.7 \mathrm{~Hz}), 3.53(\mathrm{t}, 1 \mathrm{H}, J=6.6 \mathrm{~Hz}), 2.17(\mathrm{~s}, 3 \mathrm{H}), 2.03(\mathrm{~s}, 3 \mathrm{H})$, $1.91(\mathrm{~s}, 3 \mathrm{H}) ;{ }^{13} \mathrm{C} \mathrm{NMR}\left(\mathrm{CDCl}_{3}, 125 \mathrm{MHz}\right) \delta 170.5,170.3,170.0,136.1,136.0,133.1,132.6,130.3$, $130.1,127.9,127.7,97.2,71.5,70.8,66.7,63.7,61.4,27.0,20.9,20.8,20.7,19.4 ;$ MS (FAB) $m / z 568$ $\left(\mathrm{MH}^{+}\right)$; Exact MS (FAB) Calcd for $\mathrm{C}_{28} \mathrm{H}_{29} \mathrm{~N}_{3} \mathrm{O}_{8} \mathrm{Si}: 570.2271$, found: 570.2291 .

\section{tert-Butyldiphenylsilyl $\quad 2$-Azido-2-deoxy-3,4- $O$-isopropylidene- $\beta$-D-galactopyranoside $\quad(5)$. A}

mixture of 4 (2.84 g, $5.00 \mathrm{mmol})$ in $\mathrm{MeOH}(50 \mathrm{~mL})$ containing $\mathrm{NaOMe}$ in $\mathrm{MeOH}(28 \%, 100 \mu \mathrm{L})$ was stirred for $2 \mathrm{~h}$ at room temperature. After neutralized by adding Dowex $50\left(\mathrm{H}^{+}\right)$, the resin was removed by filtration, and the filtrate was evaporated under reduced pressure. The residue was coevaporated with toluene $(3 \times 10 \mathrm{~mL})$. The residue and anhydrous $p$-TsOH $(85 \mathrm{mg}, 0.5 \mathrm{mmol})$ in acetone $(50 \mathrm{~mL})$ was stirred for $5 \mathrm{~h}$ at room temperature. The mixture was neutralized with saturated aqueous $\mathrm{NaHCO}_{3}$, and the mixture was concentrated under reduced pressure. The residue was partitioned between AcOEt (200 mL) and $\mathrm{H}_{2} \mathrm{O}(200 \mathrm{~mL})$, and the organic layer was washed with $\mathrm{H}_{2} \mathrm{O}(200 \mathrm{~mL})$, brine $(100 \mathrm{~mL})$, dried $\left(\mathrm{Na}_{2} \mathrm{SO}_{4}\right)$, and evaporated under reduced pressure. The residue was purified by flush column chromatography $\left(\mathrm{SiO}_{2}, 25 \% \mathrm{AcOEt} /\right.$ hexane $)$ to give $\mathbf{5}(3.10 \mathrm{~g}, 73 \%$ as a colorless syrup $):[\alpha]_{\mathrm{D}} 52.8^{\circ}(c$ 1.01, $\left.\mathrm{CHCl}_{3}\right) ;{ }^{1} \mathrm{H} \mathrm{NMR}\left(\mathrm{CDCl}_{3}, 500 \mathrm{MHz}\right) \delta 7.75-7.38(\mathrm{~m}, 10 \mathrm{H}), 4.43(\mathrm{~d}, 1 \mathrm{H}, J=8.3 \mathrm{~Hz}), 3.91(\mathrm{dd}$, $1 \mathrm{H}, J=1.7,5.2 \mathrm{~Hz}), 3.85(\mathrm{dd}, 1 \mathrm{H}, J=5.4,8.1 \mathrm{~Hz}), 3.66(\mathrm{dd}, 1 \mathrm{H}, J=8.1,11.9 \mathrm{~Hz}), 3.48(\mathrm{dd}, 1 \mathrm{H}, J=$ $5.6,11.9 \mathrm{~Hz}), 3.43(\mathrm{t}, 1 \mathrm{H}, J=8.1 \mathrm{~Hz}), 3.38(\mathrm{ddd}, 1 \mathrm{H}, J=1.7,5.6,8.1 \mathrm{~Hz}), 1.56(\mathrm{~s}, 3 \mathrm{H}), 1.30(\mathrm{~s}, 3 \mathrm{H})$; 
${ }^{13} \mathrm{C} \mathrm{NMR}\left(\mathrm{CDCl}_{3}, 125 \mathrm{MHz}\right) \delta 137.4,137.3,135.2,134.1,131.7,131.6,129.4,129.1,112.3,98.1,79.2$, 75.4, 74.5, 69.6, 63.7, 29.9, 28.4, 27.8, 20.6; MS (FAB) $m / z 484\left(\mathrm{MH}^{+}\right)$; Exact MS (FAB) Calcd for $\mathrm{C}_{25} \mathrm{H}_{34} \mathrm{~N}_{3} \mathrm{O}_{5} \mathrm{Si}: 484.2267$, found: 484.2251. Anal. Calcd for $\mathrm{C}_{25} \mathrm{H}_{33} \mathrm{~N}_{3} \mathrm{O}_{5} \mathrm{Si}: \mathrm{C}, 62.09 ; \mathrm{H}, 6.88 ; \mathrm{N}, 8.69$. Found: C, 62.05; H, 6.89; N, 8.73.

\section{tert-Butyldiphenylsilyl}

\section{2-Azido-2-deoxy-3,4- $O$-isopropylidene-6- $S$-phenyl-6-thio- $\beta$-D-}

galactopyranoside (6). A mixture of $5(370 \mathrm{mg}, 0.76 \mathrm{mmol})$ and $\mathrm{Tf}{ }_{2} \mathrm{O}(258 \mu \mathrm{L}, 1.56 \mathrm{mmol})$ in $\mathrm{CH}_{2} \mathrm{Cl}_{2}$ (8 $\mathrm{mL})$ containing pyridine $(129 \mu \mathrm{L}, 1.72 \mathrm{mmol})$ was stirred for $5 \mathrm{~min}$ at $-20{ }^{\circ} \mathrm{C}$. The mixture was diluted with $\mathrm{CH}_{2} \mathrm{Cl}_{2}(20 \mathrm{~mL})$, washed with $\mathrm{H}_{2} \mathrm{O}(50 \mathrm{~mL})$, saturated aqueous $\mathrm{NaHCO}_{3}(30 \mathrm{~mL})$, and brine $(100 \mathrm{~mL})$, dried $\left(\mathrm{Na}_{2} \mathrm{SO}_{4}\right)$, and evaporated under reduced pressure. A solution of PhSH $(117 \mu \mathrm{L}$, $1.17 \mathrm{mmol})$ and $\mathrm{Et}_{3} \mathrm{~N}(214 \mu \mathrm{L}, 1.56 \mathrm{mmol})$ in $\mathrm{CH}_{2} \mathrm{Cl}_{2}(8 \mathrm{~mL})$ was added to the above residue in $\mathrm{CH}_{2} \mathrm{Cl}_{2}$ $(5 \mathrm{~mL})$. The mixture was stirred for $1 \mathrm{~h}$ at room temperature, diluted with $\mathrm{CH}_{2} \mathrm{Cl}_{2}(20 \mathrm{~mL})$, and washed with $\mathrm{H}_{2} \mathrm{O}(50 \mathrm{~mL})$. The organic layer was evaporated under reduced pressure. The residue was purified by column chromatography $\left(\mathrm{SiO}_{2}, 4 \% \mathrm{AcOEt} / \mathrm{hexane}\right)$ to give 6 (406 $\mathrm{mg}, 93 \%$ as a colorless syrup): $[\alpha]_{\mathrm{D}} 21.0^{\circ}\left(c 1.11, \mathrm{CHCl}_{3}\right) ;{ }^{1} \mathrm{H} \mathrm{NMR}\left(\mathrm{CDCl}_{3}, 500 \mathrm{MHz}\right) \delta 7.73-7.16(\mathrm{~m}, 15 \mathrm{H}), 4.27(\mathrm{~d}, 1 \mathrm{H}, J=8.2 \mathrm{~Hz})$, $4.10(\mathrm{dd}, 1 \mathrm{H}, J=2.1,5.2 \mathrm{~Hz}), 3.78(\mathrm{dd}, 1 \mathrm{H}, J=5.3,8.1 \mathrm{~Hz}), 3.42(\mathrm{t}, 1 \mathrm{H}, J=8.2 \mathrm{~Hz}), 3.34(\mathrm{ddd}, 1 \mathrm{H}, J$ $=2.1,5.3,8.8 \mathrm{~Hz}), 1.54(\mathrm{~s}, 3 \mathrm{H}), 1.26(\mathrm{~s}, 3 \mathrm{H}) ;{ }^{13} \mathrm{C} \mathrm{NMR}\left(\mathrm{CDCl}_{3}, 125 \mathrm{MHz}\right) \delta 136.0,135.9,135.6,133.1$, $132.6,130.8,129.9,129.8,129.1,129.0,127.6,127.4,127.1,126.2,110.2,96.4,72.7,71.8,67.9,33.2$, 28.3, 26.8, 26.1, 19.1; MS (FAB) $m / z 576\left(\mathrm{MH}^{+}\right)$; Exact MS (FAB) Calcd for $\mathrm{C}_{31} \mathrm{H}_{38} \mathrm{~N}_{3} \mathrm{O}_{4} \mathrm{SSi}:$ 576.2352, found: 576.2330 .

(2S,3R,4S,5R)-2-Azido-3,4-(dimethylmethylenedioxy)-6-phenylthio-1,5-hexanediol (7). A mixture of $6(3.60 \mathrm{~g}, 6.26 \mathrm{mmol})$ and TBAF $(1 \mathrm{M}, 6.89 \mathrm{~mL}, 6.89 \mathrm{mmol})$ in THF (60 mL) was stirred for $30 \mathrm{~min}$ at $-20{ }^{\circ} \mathrm{C}$ and evaporated under reduced pressure. Sodium borohydride $(950 \mathrm{mg}, 25.0 \mathrm{mmol})$ was added to the above residue in $\mathrm{MeOH}(60 \mathrm{~mL})$ at $-20{ }^{\circ} \mathrm{C}$, and the mixture was stirred for $30 \mathrm{~min}$. The mixture was evaporated under reduced pressure, and then the residue was coevaporated with $\mathrm{MeOH}(3$ 
x $10 \mathrm{~mL})$. The residue was partitioned between AcOEt $(200 \mathrm{~mL})$ and $\mathrm{H}_{2} \mathrm{O}(200 \mathrm{~mL})$, and the organic layer was washed with $\mathrm{H}_{2} \mathrm{O}(200 \mathrm{~mL})$ and brine $(100 \mathrm{~mL})$, dried $\left(\mathrm{Na}_{2} \mathrm{SO}_{4}\right)$, and evaporated under reduced pressure. The residue was purified by column chromatography $\left(\mathrm{SiO}_{2}, 33 \% \mathrm{AcOEt} / \mathrm{hexane}\right)$ to give 7 (1.83 g, 86\% as a colorless syrup): $[\alpha]_{\mathrm{D}}-29.8^{\circ}\left(c 0.99, \mathrm{CHCl}_{3}\right) ;{ }^{1} \mathrm{H} \mathrm{NMR}\left(\mathrm{CDCl}_{3}, 500 \mathrm{MHz}\right) \delta$ $7.38(\mathrm{~d}, 2 \mathrm{H}, J=7.7 \mathrm{~Hz}), 7.29(\mathrm{t}, 2 \mathrm{H}, J=7.5 \mathrm{~Hz}), 7.21(\mathrm{t}, 1 \mathrm{H}, J=7.4 \mathrm{~Hz}), 4.31(\mathrm{dd}, 1 \mathrm{H}, J=1.8,6.8$ $\mathrm{Hz}), 4.27(\mathrm{t}, 1 \mathrm{H}, J=6.5 \mathrm{~Hz}), 3.80(\mathrm{~m}, 2 \mathrm{H}), 3.65(\mathrm{~m}, 2 \mathrm{H}), 3.17(\mathrm{dd}, 1 \mathrm{H}, J=6.5,13.7 \mathrm{~Hz}), 3.06(\mathrm{dd}, 1 \mathrm{H}$, $J=6.8,13.7 \mathrm{~Hz}), 2.83\left(\mathrm{~d}, 1 \mathrm{H}, J=6.7 \mathrm{~Hz}\right.$, exchanged with $\left.\mathrm{D}_{2} \mathrm{O}\right), 2.27(\mathrm{t}, 1 \mathrm{H}, J=5.7 \mathrm{~Hz}$, exchanged with $\left.\mathrm{D}_{2} \mathrm{O}\right), 1.56(\mathrm{~s}, 3 \mathrm{H}), 1.36(\mathrm{~s}, 3 \mathrm{H}) ;{ }^{13} \mathrm{C} \mathrm{NMR}\left(\mathrm{CDCl}_{3}, 125 \mathrm{MHz}\right) \delta 135.2,129.8,129.3,129.2,128.6$, 126.7, 126.5, 126.1, 108.9, 68.0, 63.0, 61.7, 38.2, 26.5; MS (FAB) $m / z 340\left(\mathrm{MH}^{+}\right)$; Exact MS (FAB) Calcd for $\mathrm{C}_{15} \mathrm{H}_{22} \mathrm{~N}_{3} \mathrm{O}_{4} \mathrm{~S}: 340.1331$, found: 340.1339 .

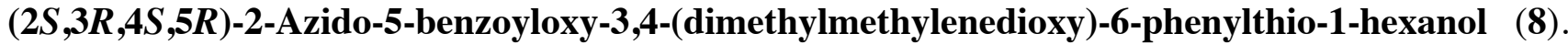

A mixture of 7 (500 mg, $1.47 \mathrm{mmol}), \mathrm{TBSCl}(243 \mathrm{mg}, 1.67 \mathrm{mmol})$, and imidazole (220 $\mathrm{mg}, 3.23$ $\mathrm{mmol})$ in DMF $(20 \mathrm{~mL})$ was stirred for $1 \mathrm{~h}$ at $0{ }^{\circ} \mathrm{C}$. After $\mathrm{MeOH}(5 \mathrm{~mL})$ was added, the mixture was partitioned between AcOEt $(100 \mathrm{~mL})$ and $\mathrm{H}_{2} \mathrm{O}(100 \mathrm{~mL})$, and the organic layer was washed with $\mathrm{H}_{2} \mathrm{O}$ $(100 \mathrm{~mL})$ and brine $(50 \mathrm{~mL})$, dried $\left(\mathrm{Na}_{2} \mathrm{SO}_{4}\right)$, and evaporated under reduced pressure. $\mathrm{BzCl}(256 \mu \mathrm{L}$, $2.21 \mathrm{mmol})$ was added to the residue in pyridine $(20 \mathrm{~mL})$, and the mixture was stirred for $12 \mathrm{~h}$ at room temperature. After $\mathrm{MeOH}(1 \mathrm{~mL})$ was added, the mixture was evaporated under reduced pressure. The residue was partitioned between AcOEt $(100 \mathrm{~mL})$ and $\mathrm{H}_{2} \mathrm{O}(100 \mathrm{~mL})$, and the organic layer was washed with $\mathrm{H}_{2} \mathrm{O}(100 \mathrm{~mL})$ and brine $(50 \mathrm{~mL})$, dried $\left(\mathrm{Na}_{2} \mathrm{SO}_{4}\right)$, and evaporated under reduced pressure. A mixture of the residue and TBAF $(1 \mathrm{M}, 1.67 \mathrm{~mL}, 1.67 \mathrm{mmol})$ in THF $(20 \mathrm{~mL})$ was stirred for $2 \mathrm{~h}$ at

$0{ }^{\circ} \mathrm{C}$. The mixture was evaporated under reduced pressure, and the residue was purified by column chromatography $\left(\mathrm{SiO}_{2}, 10 \% \mathrm{AcOEt} /\right.$ hexane $)$ to give $\mathbf{8}\left(534 \mathrm{mg}, 83 \%\right.$ as a colorless syrup): $[\alpha]_{\mathrm{D}}-52.7^{\circ}$ (c 1.04, $\left.\mathrm{CHCl}_{3}\right) ;{ }^{1} \mathrm{H} \mathrm{NMR}\left(\mathrm{CDCl}_{3}, 500 \mathrm{MHz}\right) \delta 8.12-7.18(\mathrm{~m}, 10 \mathrm{H}), 5.22(\mathrm{ddd}, 1 \mathrm{H}, J=1.6,5.2,8.8$ $\mathrm{Hz}), 4.70(\mathrm{dd}, 1 \mathrm{H}, J=1.6,6.4 \mathrm{~Hz}), 4.39(\mathrm{~m}, 1 \mathrm{H}), 3.53(\mathrm{~m}, 2 \mathrm{H}), 3.47(\mathrm{dd}, 1 \mathrm{H}, J=5.2,13.7 \mathrm{~Hz}), 3.26$ 
$(\mathrm{dd}, 1 \mathrm{H}, J=8.8,13.7 \mathrm{~Hz}), 1.96\left(\mathrm{t}, 1 \mathrm{H}, J=5.2 \mathrm{~Hz}\right.$, exchanged with $\left.\mathrm{D}_{2} \mathrm{O}\right), 1.67(\mathrm{~s}, 3 \mathrm{H}), 1.44(\mathrm{~s}, 3 \mathrm{H}) ;{ }^{13} \mathrm{C}$ $\operatorname{NMR}\left(\mathrm{CDCl}_{3}, 125 \mathrm{MHz}\right) \delta 166.7,135.2,133.7,130.1,130.0,129.6,129.3,128.8,126.7,109.5,75.1$, 72.1, 62.9, 61.6, 33.8, 26.8, 25.6; MS (FAB) $m / z 444\left(\mathrm{MH}^{+}\right)$; Exact MS (FAB) Calcd for $\mathrm{C}_{22} \mathrm{H}_{26} \mathrm{~N}_{3} \mathrm{O}_{5} \mathrm{~S}$ : 444.1593, found: 444.1580 .

\section{$(2 S, 3 R, 4 S, 5 R)-2$-Azido-5-benzoyloxy-3,4-(dimethylmethylenedioxy)-1,6-di(phenylthio)hexane}

(9). A mixture of $8(570 \mathrm{mg}, 1.28 \mathrm{mmol})$ and $\mathrm{Tf}_{2} \mathrm{O}(261 \mu \mathrm{L}, 1.53 \mathrm{mmol})$ in $\mathrm{CH}_{2} \mathrm{Cl}_{2}(15 \mathrm{~mL})$ containing pyridine $(129 \mu \mathrm{L}, 1.72 \mathrm{mmol})$ was stirred for $5 \mathrm{~min}$ at $-20{ }^{\circ} \mathrm{C}$, and diluted with $\mathrm{CH}_{2} \mathrm{Cl}_{2}(20 \mathrm{~mL})$. The mixture was washed with $\mathrm{H}_{2} \mathrm{O}(50 \mathrm{~mL})$, saturated aqueous $\mathrm{NaHCO}_{3}(30 \mathrm{~mL})$, and brine $(100 \mathrm{~mL})$, dried $\left(\mathrm{Na}_{2} \mathrm{SO}_{4}\right)$, and evaporated under reduced pressure. A mixture of the residue in $\mathrm{CH}_{2} \mathrm{Cl}_{2}(15 \mathrm{~mL})$, $\mathrm{PhSH}(394 \mu \mathrm{L}, 3.84 \mathrm{mmol})$, and $\mathrm{Et}_{3} \mathrm{~N}(720 \mu \mathrm{L}, 5.12 \mathrm{mmol})$ was stirred for $1 \mathrm{~h}$ at room temperature, diluted with $\mathrm{CH}_{2} \mathrm{Cl}_{2}(20 \mathrm{~mL})$, and washed with $\mathrm{H}_{2} \mathrm{O}(50 \mathrm{~mL})$. The organic layer was evaporated under reduced pressure. The residue was purified by column chromatography $\left(\mathrm{SiO}_{2}, 4 \% \mathrm{AcOEt} / \mathrm{hexane}\right)$ to give 9 (614 mg, $90 \%$ as a colorless syrup): $[\alpha]_{\mathrm{D}} 23.9^{\circ}\left(c 1.02, \mathrm{CHCl}_{3}\right) ;{ }^{1} \mathrm{H} \mathrm{NMR}\left(\mathrm{CDCl}_{3}, 500 \mathrm{MHz}\right) \delta$ 8.03-7.12 (m, 15H), 5.07 (ddd, 1H, J=3.0, 4.8, 8.3 Hz), 4.62 (dd, 1H, $J=3.0,6.5 \mathrm{~Hz}), 4.41(\mathrm{t}, 1 \mathrm{H}, J=$ $6.8 \mathrm{~Hz}), 3.45(\mathrm{dd}, 1 \mathrm{H}, J=6.8,12.3 \mathrm{~Hz}), 3.41(\mathrm{dd}, 1 \mathrm{H}, J=4.9,13.8 \mathrm{~Hz}), 3.17(\mathrm{dd}, 1 \mathrm{H}, J=8.4,13.8 \mathrm{~Hz})$, $2.97(\mathrm{dd}, 1 \mathrm{H}, J=5.3,13.8 \mathrm{~Hz}), 2.92(\mathrm{dd}, 1 \mathrm{H}, J=7.0,13.7 \mathrm{~Hz}), 1.61(\mathrm{~s}, 3 \mathrm{H}), 1.39(\mathrm{~s}, 3 \mathrm{H}) ;{ }^{13} \mathrm{C} \mathrm{NMR}$ $\left(\mathrm{CDCl}_{3}, 125 \mathrm{MHz}\right) \delta 166.2,135.0,134.5,133.5,131.2,130.1,129.9,129.8,129.5,129.4,128.7,127.6$, 126.9, 109.7, 78.3 75.1, 71.7, 59.5, 36.9, 33.8, 25.7, 25.4; MS (FAB) $m / z 536\left(\mathrm{MH}^{+}\right)$; Exact MS (FAB) Calcd for $\mathrm{C}_{28} \mathrm{H}_{30} \mathrm{~N}_{3} \mathrm{O}_{4} \mathrm{~S}_{2}: 536.1677$, found: 536.1670 .

(2S,3R,4S,5R)-2-Azido-3,4-(dimethylmethylenedioxy)-1,6-di(phenylthio)hexane (10). A mixture of 9 (4.70 g, $8.74 \mathrm{mmol})$ in $\mathrm{MeOH}(90 \mathrm{~mL})$ containing $\mathrm{NaOMe}$ in $\mathrm{MeOH}(28 \%, 0.8 \mathrm{~mL})$ was stirred for $1 \mathrm{~h}$ at room temperature. After neutralized by adding Dowex $50\left(\mathrm{H}^{+}\right)$, the resin was removed by filtration, and the filtrate was evaporated under reduced pressure. The residue was purified by column chromatography $\left(\mathrm{SiO}_{2}, 4 \% \mathrm{AcOEt} /\right.$ hexane) to give $\mathbf{1 0}$ ( $3.40 \mathrm{~g}, 90 \%$ as a colorless syrup): $[\alpha]_{\mathrm{D}}-14.5^{\circ}$ 
$\left(c 1.11, \mathrm{CHCl}_{3}\right) ;{ }^{1} \mathrm{H} \mathrm{NMR}\left(\mathrm{CDCl}_{3}, 500 \mathrm{MHz}\right) \delta 7.37-7.20(\mathrm{~m}, 15 \mathrm{H}), 4.32(\mathrm{dd}, 1 \mathrm{H}, J=4.8,6.9 \mathrm{~Hz})$, $4.26(\mathrm{dd}, 1 \mathrm{H}, J=2.8,6.9 \mathrm{~Hz}), 3.68(\mathrm{ddd}, 1 \mathrm{H}, J=2.9,6.4,9.1 \mathrm{~Hz}), 3.57(\mathrm{dd}, 1 \mathrm{H}, J=6.4,11.5 \mathrm{~Hz}), 3.06$ $(\mathrm{m}, 3 \mathrm{H}), 2.98(\mathrm{dd}, 1 \mathrm{H}, J=6.5,13.7 \mathrm{~Hz}), 1.51\left(\mathrm{~d}, 1 \mathrm{H}, J=5.8 \mathrm{~Hz}\right.$, exchanged with $\left.\mathrm{D}_{2} \mathrm{O}\right), 1.54(\mathrm{~s}, 3 \mathrm{H})$, $1.33(\mathrm{~s}, 3 \mathrm{H}) ;{ }^{13} \mathrm{C} \mathrm{NMR}\left(\mathrm{CDCl}_{3}, 125 \mathrm{MHz}\right) \delta 135.3,134.7,131.2,130.1,129.5,129.4,127.6,127.0$, 126.3, 109.3, 68.1, 60.6, 59.6, 38.5, 36.9, 26.6, 25.0, 21.3; MS (FAB) $m / z 432\left(\mathrm{MH}^{+}\right)$; Exact MS (FAB) Calcd for $\mathrm{C}_{21} \mathrm{H}_{26} \mathrm{~N}_{3} \mathrm{O}_{3} \mathrm{~S}_{2}: 432.1415$, found: 432.1422 .

$(3 R, 4 R, 5 S)-5-A z i d o-3,4-(d i m e t h y l m e t h y l e n e d i o x y)-1,6-d i(p h e n y l t h i o)-2-h e x a n o n e$

(11). A mixture of 10 (1.20 g, $2.79 \mathrm{mmol})$ and Dess-Martin periodinane $(1.79 \mathrm{~g}, 4.19 \mathrm{mmol})$ in $\mathrm{CH}_{2} \mathrm{Cl}_{2}(30$ $\mathrm{mL}$ ) was stirred for $30 \mathrm{~min}$ at room temperature. After a mixture of saturated aqueous $\mathrm{NaHCO}_{3}$ and saturated aqueous $\mathrm{Na}_{2} \mathrm{~S}_{2} \mathrm{O}_{3}(5: 1,50 \mathrm{~mL})$ was added, the mixture was vigorously stirred until the organic layer turned to be clear. The organic layer was washed with $\mathrm{H}_{2} \mathrm{O}(50 \mathrm{~mL})$ and brine $(50 \mathrm{~mL})$, dried $\left(\mathrm{Na}_{2} \mathrm{SO}_{4}\right)$, and evaporated under reduced pressure. The residue was purified by column chromatography $\left(\mathrm{SiO}_{2}, 8 \%\right.$ hexane/AcOEt) to give $11\left(1.20 \mathrm{~g}, 99 \%\right.$. as a colorless syrup): $[\alpha]_{\mathrm{D}} 23.9^{\circ}\left(c 1.17, \mathrm{CHCl}_{3}\right) ;{ }^{1} \mathrm{H}$ $\operatorname{NMR}\left(\mathrm{CDCl}_{3}, 500 \mathrm{MHz}\right) \delta 7.40-7.19(\mathrm{~m}, 15 \mathrm{H}), 4.69(\mathrm{dd}, 1 \mathrm{H}, J=1.1,8.7 \mathrm{~Hz}), 4.62(\mathrm{~d}, 1 \mathrm{H}, J=8.7 \mathrm{~Hz})$, $4.19(\mathrm{~d}, 1 \mathrm{H}, J=15.7 \mathrm{~Hz}), 3.93(\mathrm{~d}, 1 \mathrm{H}, J=15.7 \mathrm{~Hz}), 3.34(\mathrm{t}, 1 \mathrm{H}, J=6.6 \mathrm{~Hz}), 3.27(\mathrm{~s}, 2 \mathrm{H}), 1.60(\mathrm{~s}, 3 \mathrm{H})$, $1.32(\mathrm{~s}, 3 \mathrm{H}) ;{ }^{13} \mathrm{C} \mathrm{NMR}\left(\mathrm{CDCl}_{3}, 125 \mathrm{MHz}\right) \delta 204.4,135.0,134.4,130.5,130.2,129.3,129.0,127.2$, 126.9, 110.5, 79.7, 78.7, 57.7, 42.1, 34.8, 25.9, 23.8; MS (FAB) $m / z 430\left(\mathrm{MH}^{+}\right)$; Exact MS (FAB) Calcd for $\mathrm{C}_{21} \mathrm{H}_{24} \mathrm{~N}_{3} \mathrm{O}_{3} \mathrm{~S}_{2}: 430.1259$, found: 430.1254 .

\section{1-[10-Azido-2,3-di-O-(tert-butyldimethylsilyl)-6,10,11-trideoxy-8,9-O-isopropylidene-11-S-} phenyl-11-thio-L-lyxo-D-allo-undeculofuranosyl-(1,4)]uracil (13a) and 1-[10-Azido-2,3-di-O-(tertbutyldimethylsilyl)-6,10,11-trideoxy-8,9-O-isopropylidene-11-S-phenyl-11-thio-L-lyxo-L-taloundeculofuranosyl-(1,4)]uracil (13b). Compound $11(85 \mathrm{mg}, 0.2 \mathrm{mmol})$ in THF (2 mL) was added dropwise to a THF solution of $\operatorname{SmI}_{2}(0.1 \mathrm{M}, 4.4 \mathrm{~mL}, 0.44 \mathrm{mmol})$ at $-40{ }^{\circ} \mathrm{C}$. After the TLC analysis indicated the disappearance of $\mathbf{1 1}$, oxygen gas was passed through the mixture. Then, 12 (94 $\mathrm{mg}, 0.2$ 
$\mathrm{mmol})$ in THF ( $2 \mathrm{~mL})$ was added dropwise, and the mixture was stirred for $15 \mathrm{~min}$ at $-40{ }^{\circ} \mathrm{C}$. After the mixture was allowed to warm to room temperature, saturated aqueous $\mathrm{NH}_{4} \mathrm{Cl}$ was added. The mixture was filtrated through a Celite pad, and the filtrate was partitioned between AcOEt $(50 \mathrm{~mL})$ and $\mathrm{H}_{2} \mathrm{O}(50$ $\mathrm{mL})$, and the organic layer was washed with saturated aqueous $\mathrm{NaHCO}_{3}(20 \mathrm{~mL})$ and brine $(20 \mathrm{~mL})$, dried $\left(\mathrm{Na}_{2} \mathrm{SO}_{4}\right)$, and evaporated under reduced pressure. The residue was purified by flush column chromatography $\left(\mathrm{SiO}_{2}, 33 \% \mathrm{AcOEt} / \mathrm{hexane}\right)$ to give 13a $(74 \mathrm{mg}, 47 \%$ as a white foam, fast moving) and $\mathbf{1 3 b}$ (38 $\mathrm{mg}, 24 \%$ as a white foam, slow moving).

For 13a: ${ }^{1} \mathrm{H} \mathrm{NMR}\left(\mathrm{CDCl}_{3}, 500 \mathrm{MHz}\right) \delta 8.95$ (br s, $1 \mathrm{H}$, exchanged with $\left.\mathrm{D}_{2} \mathrm{O}\right), 8.04(\mathrm{~d}, 1 \mathrm{H}, J=8.2 \mathrm{~Hz})$, $7.43(\mathrm{~d}, 2 \mathrm{H}, J=7.7 \mathrm{~Hz}), 7.53(\mathrm{t}, 2 \mathrm{H}, J=7.8 \mathrm{~Hz}), 7.26(\mathrm{~d}, 1 \mathrm{H}, J=7.7 \mathrm{~Hz}), 5.83(\mathrm{~d}, 1 \mathrm{H}, J=4.6 \mathrm{~Hz})$, $5.69(\mathrm{dd}, 1 \mathrm{H}, J=1.8,8.1 \mathrm{~Hz}), 4.72(\mathrm{~d}, 1 \mathrm{H}, J=8.8 \mathrm{~Hz}), 4.48(\mathrm{~d}, 1 \mathrm{H}, J=8.8 \mathrm{~Hz}), 4.31(\mathrm{t}, 1 \mathrm{H}, J=4.5$ $\mathrm{Hz}), 4.26(\mathrm{~d}, 1 \mathrm{H}, J=10.2 \mathrm{~Hz}), 3.93(\mathrm{~d}, 1 \mathrm{H}, J=4.2 \mathrm{~Hz}), 3.43(\mathrm{~d}, 1 \mathrm{H}, J=2.1 \mathrm{~Hz}), 3.33(\mathrm{~m}, 3 \mathrm{H}), 3.29$ $(\mathrm{dd}, 1 \mathrm{H}, J=10.1,19.3 \mathrm{~Hz}), 2.88(\mathrm{dd}, 1 \mathrm{H}, J=1.9,19.3 \mathrm{~Hz}), 1.62(\mathrm{~s}, 3 \mathrm{H}), 1.31(\mathrm{~s}, 3 \mathrm{H}), 0.92(\mathrm{~s}, 9 \mathrm{H})$, $0.90(\mathrm{~s}, 9 \mathrm{H}), 0.11(\mathrm{~s}, 6 \mathrm{H}), 0.07(\mathrm{~s}, 6 \mathrm{H}) ;{ }^{13} \mathrm{C} \mathrm{NMR}\left(\mathrm{CDCl}_{3}, 125 \mathrm{MHz}\right) \delta 212.4,163.6,150.7,141.4$, $134.6,130.7,129.5,127.5,110.8,102.3,90.0,87.1,80.6,79.2,75.4,72.4,65.5,57.9,44.4,35.2,26.2$, 26.1 26.0, 24.0, 18.3, 18.2, -4.2, -4.4, -4.5, -4.6; MS (FAB) m/z $792\left(\mathrm{MH}^{+}\right)$; Exact MS (FAB) Calcd for $\mathrm{C}_{36} \mathrm{H}_{58} \mathrm{~N}_{5} \mathrm{O}_{9} \mathrm{SSi}_{2}$ : 792.3493, found: 792.3521 .

For 13b: ${ }^{1} \mathrm{H} \mathrm{NMR}\left(\mathrm{CDCl}_{3}, 500 \mathrm{MHz}\right) \delta 8.87$ (br s, $1 \mathrm{H}$, exchanged with $\left.\mathrm{D}_{2} \mathrm{O}\right), 7.75(\mathrm{~d}, 1 \mathrm{H}, J=8.1 \mathrm{~Hz})$, $7.41(\mathrm{~d}, 2 \mathrm{H}, J=7.6 \mathrm{~Hz}), 7.32(\mathrm{t}, 2 \mathrm{H}, J=7.4 \mathrm{~Hz}), 7.26(\mathrm{~d}, 1 \mathrm{H}, J=7.4 \mathrm{~Hz}), 5.85(\mathrm{~d}, 1 \mathrm{H}, J=6.6 \mathrm{~Hz})$, $5.73(\mathrm{dd}, 1 \mathrm{H}, J=1.7,8.1 \mathrm{~Hz}), 4.71(\mathrm{~d}, 1 \mathrm{H}, J=8.8 \mathrm{~Hz}), 4.47(\mathrm{~d}, 1 \mathrm{H}, J=8.8 \mathrm{~Hz}), 4.36(\mathrm{dd}, 1 \mathrm{H}, J=4.5$, $6.5 \mathrm{~Hz}), 4.29(\mathrm{~d}, 1 \mathrm{H}, J=11.1 \mathrm{~Hz}), 4.19(\mathrm{dd}, 1 \mathrm{H}, J=1.4,4.2 \mathrm{~Hz}), 3.86(\mathrm{br} \mathrm{s}, 1 \mathrm{H}), 3.65(\mathrm{~d}, 1 \mathrm{H}, J=2.0$ Hz), 3.29 (br s, 3H), $3.07(\mathrm{~d}, 1 \mathrm{H}, J=7.7 \mathrm{~Hz}), 2.76(\mathrm{dd}, 1 \mathrm{H}, J=10.6,18.7 \mathrm{~Hz}), 1.59(\mathrm{~s}, 3 \mathrm{H}), 1.31(\mathrm{~s}$, $3 \mathrm{H}), 0.93(\mathrm{~s}, 9 \mathrm{H}), 0.86(\mathrm{~s}, 9 \mathrm{H}), 0.12(\mathrm{~s}, 3 \mathrm{H}), 0.11(\mathrm{~s}, 3 \mathrm{H}), 0.03(\mathrm{~s}, 3 \mathrm{H}),-0.02(\mathrm{~s}, 3 \mathrm{H}) ;{ }^{13} \mathrm{C} \mathrm{NMR}\left(\mathrm{CDCl}_{3}\right.$, $125 \mathrm{MHz}) \delta 212.1,163.4,150.6,141.8,134.6,130.8,130.7,129.5,127.5,110.8,102.7,89.6,88.4$, $80.5,79.2,74.8,71.8,67.8,57.7,43.7,35.1,26.1,26.0,24.0,23.9,18.3,18.2,-4.1,-4.2,-4.4,-4.6$; 
MS (FAB) m/z $792\left(\mathrm{MH}^{+}\right)$; Exact MS (FAB) Calcd for $\mathrm{C}_{36} \mathrm{H}_{58} \mathrm{~N}_{5} \mathrm{O}_{9} \mathrm{SSi}_{2}$ : 792.3493, found: 792.3486 .

\section{1-[10-Azido-2,3-di-O-(tert-butyldimethylsilyl)-6,10,11-trideoxy-8,9-O-isopropylidene-11-S-}

phenyl-11-thio-L-galacto-D-allo-undecofuranosyl-(1,4)]uracil (14). Sodium borohydride (7.1mg, $189 \mu \mathrm{mol})$ was added to a mixture of $\mathrm{AcOH}$ and $\mathrm{CH}_{2} \mathrm{Cl}_{2}(1: 2,1 \mathrm{~mL})$ at $-20{ }^{\circ} \mathrm{C}$, and then a solution of 13a $(50 \mathrm{mg}, 63 \mu \mathrm{mol})$ in $\mathrm{CH}_{2} \mathrm{Cl}_{2}(0.5 \mathrm{~mL})$ was added dropwise to the mixture. After being stirred for $30 \min$ at $-20{ }^{\circ} \mathrm{C}$, the mixture was evaporated under reduced pressure, and the residue was coevaporated with $\mathrm{MeOH}(3 \times 1 \mathrm{~mL})$. The residue was partitioned between AcOEt $(30 \mathrm{~mL})$ and $\mathrm{H}_{2} \mathrm{O}$ $(20 \mathrm{~mL})$, and the organic layer was washed with saturated aqueous $\mathrm{NaHCO}_{3}(20 \mathrm{~mL})$ and brine $(100$ $\mathrm{mL})$, dried $\left(\mathrm{Na}_{2} \mathrm{SO}_{4}\right)$, and evaporated under reduced pressure. The residue was purified by column chromatography $\left(\mathrm{SiO}_{2}, 33 \% \mathrm{AcOEt} /\right.$ hexane $)$ to give $14\left(55 \mathrm{mg}\right.$, quant. as a white foam): ${ }^{1} \mathrm{H}$ NMR $\left(\mathrm{CDCl}_{3}, 500 \mathrm{MHz}\right) \delta 9.49$ (br s, $1 \mathrm{H}$, exchanged with $\left.\mathrm{D}_{2} \mathrm{O}\right), 7.61(\mathrm{~d}, 1 \mathrm{H}, J=8.0 \mathrm{~Hz}), 7.42(\mathrm{~d}, 2 \mathrm{H}, J=$ $7.8 \mathrm{~Hz}), 7.29(\mathrm{t}, 2 \mathrm{H}, J=7.8 \mathrm{~Hz}), 7.21(\mathrm{~d}, 1 \mathrm{H}, J=7.7 \mathrm{~Hz}), 5.69(\mathrm{~d}, 1 \mathrm{H}, J=8.0 \mathrm{~Hz}), 5.69(\mathrm{~d}, 1 \mathrm{H}, J=5.7$ $\mathrm{Hz}), 4.60(\mathrm{t}, 1 \mathrm{H}, J=5.1 \mathrm{~Hz}), 4.46(\mathrm{dd}, 1 \mathrm{H}, J=2.2,6.4 \mathrm{~Hz}), 4.24(\mathrm{ddd}, 1 \mathrm{H}, J=6.3,9.6,12.6 \mathrm{~Hz}), 4.13$ $(\mathrm{d}, 2 \mathrm{H}), 4.08(\mathrm{dd}, 1 \mathrm{H}, J=6.7,9.4 \mathrm{~Hz}), 3.91(\mathrm{~d}, 1 \mathrm{H}, J=2.4 \mathrm{~Hz}), 3.68(\mathrm{dd}, 1 \mathrm{H}, J=2.0,7.1 \mathrm{~Hz}), 3.43(\mathrm{~d}$, $1 \mathrm{H}, J=6.2 \mathrm{~Hz}), 3.33(\mathrm{dd}, 1 \mathrm{H}, J=7.1,13.6 \mathrm{~Hz}), 3.27(\mathrm{dd}, 1 \mathrm{H}, J=4.3,13.6 \mathrm{~Hz}), 2.09(\mathrm{ddd}, 1 \mathrm{H}, J=3.3$, 3.8, $13.8 \mathrm{~Hz}), 1.70(\mathrm{ddd}, 1 \mathrm{H}, J=1.8,6.5,13.8 \mathrm{~Hz}), 1.49(\mathrm{~s}, 3 \mathrm{H}), 1.31(\mathrm{~s}, 3 \mathrm{H}), 0.90(\mathrm{~s}, 9 \mathrm{H}), 0.87(\mathrm{~s}, 9 \mathrm{H})$, $0.09(\mathrm{~s}, 3 \mathrm{H}), 0.08(\mathrm{~s}, 3 \mathrm{H}), 0.07(\mathrm{~s}, 3 \mathrm{H}), 0.01(\mathrm{~s}, 3 \mathrm{H}) ;{ }^{13} \mathrm{C} \mathrm{NMR}\left(\mathrm{CDCl}_{3}, 125 \mathrm{MHz}\right) \delta 163.7,150.8$, $143.9,135.2,130.7,129.3,127.1,109.3,102.4,94.8,89.1,78.7,77.9,73.2,73.0,67.7,67.6,58.6,38.1$, $36.5,27.0,26.1,26.0,25.1,18.3,18.2,-4.2,-4.4,-4.5,-4.7$; MS (FAB) $m / z 794\left(\mathrm{MH}^{+}\right)$; Exact MS (FAB) Calcd for $\mathrm{C}_{36} \mathrm{H}_{60} \mathrm{~N}_{5} \mathrm{O}_{9} \mathrm{SSi}_{2}: 794.3650$, found: 794.3666 .

\section{1-[10-Azido-2,3-di-O-(tert-butyldimethylsilyl)-6,10,11-trideoxy-8,9-O-isopropylidene-11-}

phenylsulfinyl-L-galacto-D-allo-undecofuranosyl]uracil (15). A mixture of 14 (30 mg, 26 umol) and mCPBA $(4.6 \mathrm{mg}, 26 \mu \mathrm{mol})$ in $\mathrm{CH}_{2} \mathrm{Cl}_{2}(5 \mathrm{~mL})$ was stirred for $30 \mathrm{~min}$ at $0{ }^{\circ} \mathrm{C}$. After a mixture of saturated aqueous $\mathrm{NaHCO}_{3}$ and saturated aqous $\mathrm{Na}_{2} \mathrm{~S}_{2} \mathrm{O}_{3}(4: 1,5 \mathrm{~mL})$ was added, the organic layer was 
washed with brine $(5 \mathrm{~mL})$, dried $\left(\mathrm{Na}_{2} \mathrm{SO}_{4}\right)$, and evaporated under reduced pressure. The residue was purified by column chromatography $\left(\mathrm{SiO}_{2}, 66 \% \mathrm{AcOEt} /\right.$ hexane $)$ to give a diastereomeric mixture of $\mathbf{1 5}$ (32 mg, quant. as a white foam): MS (FAB) $\mathrm{m} / z \quad 810\left(\mathrm{MH}^{+}\right)$; Exact MS (FAB) Calcd for $\mathrm{C}_{36} \mathrm{H}_{60} \mathrm{~N}_{5} \mathrm{O}_{10} \mathrm{SSi}_{2}: 810.3599$, found: 810.3598 .

Thioglycoside 17. A mixture of $\mathbf{1 5}(7.0 \mathrm{mg}, 8.7 \mu \mathrm{mol})$ and $\mathrm{Tf}_{2} \mathrm{O}(10.7 \mu \mathrm{L}, 52 \mu \mathrm{mol})$ in $\mathrm{CH}_{2} \mathrm{Cl}_{2}(100$ $\mu \mathrm{L})$ containing pyridine $(6.6 \mu \mathrm{L}, 104 \mu \mathrm{mol})$ was stirred for $5 \mathrm{~min}$ at $-20{ }^{\circ} \mathrm{C}$, and diluted with $\mathrm{CH}_{2} \mathrm{Cl}_{2}(5$ $\mathrm{mL})$. The mixture was washed with $\mathrm{H}_{2} \mathrm{O}(3 \mathrm{~mL})$, saturated aqueous $\mathrm{NaHCO}_{3}(3 \mathrm{~mL})$, and brine $(3 \mathrm{~mL})$, dried $\left(\mathrm{Na}_{2} \mathrm{SO}_{4}\right)$, and evaporated under reduced pressure. The residue was purified by column chromatography $\left(\mathrm{SiO}_{2}, 33 \%\right.$ AcOEt/hexane) to give an inseparable mixture of $\mathbf{1 7}$ and $\mathbf{1 3 a}(5.7 \mathrm{mg}$, $89 \%$ as a glass, the ratio of $\mathbf{1 7}$ and $\mathbf{1 3 a}$ was $62: 38$ by ${ }^{1} \mathrm{H}$ NMR). To isolate pure $\mathbf{1 7}$, the next experiment was performed. $\mathrm{NaBH}_{4}(9.4 \mathrm{mg}, 189 \mu \mathrm{mol})$ was added to a mixture of $\mathrm{AcOH}$ and $\mathrm{CH}_{2} \mathrm{Cl}_{2}(1: 2,2 \mathrm{~mL})$ at $-20{ }^{\circ} \mathrm{C}$, and then the mixture of $\mathbf{1 7}$ and $\mathbf{1 3 a}(50 \mathrm{mg}, 63 \mu \mathrm{mol}$, the ratio of $\mathbf{1 7}$ and $\mathbf{1 3 a}$ was $57: 43)$ in $\mathrm{CH}_{2} \mathrm{Cl}_{2}(1 \mathrm{~mL})$ was added dropwise to the above mixture. After being stirred for $30 \mathrm{~min}$, the mixture was evaporated under reduced pressure, and the residue was coevaporated with $\mathrm{MeOH}(3 \times 2 \mathrm{~mL})$. The residue was partitioned between AcOEt $(30 \mathrm{~mL})$ and $\mathrm{H}_{2} \mathrm{O}(20 \mathrm{~mL})$, and the organic layer was washed with saturated aqueous $\mathrm{NaHCO}_{3}(20 \mathrm{~mL})$ and brine $(10 \mathrm{~mL})$, dried $\left(\mathrm{Na}_{2} \mathrm{SO}_{4}\right)$, and evaporated under reduced pressure. The residue was purified by flash column chromatography $\left(\mathrm{SiO}_{2}, 33 \%\right.$ AcOEt/hexane) to give $\mathbf{1 7}$ (26 mg, 51.6\% as a white foam, fast moving) and $\mathbf{1 4}$ (23 $\mathrm{mg}, 46 \%$ as a white foam, slow moving).

For 17: ${ }^{1} \mathrm{H} \mathrm{NMR}\left(\mathrm{CDCl}_{3}, 500 \mathrm{MHz}\right) \delta 8.68\left(\right.$ br s, $1 \mathrm{H}$, exchanged with $\left.\mathrm{D}_{2} \mathrm{O}\right), 7.79(\mathrm{~d}, 1 \mathrm{H}, J=8.1 \mathrm{~Hz})$, $7.51-7.30(\mathrm{~m}, 5 \mathrm{H}), 5.70(\mathrm{~d}, 1 \mathrm{H}, J=8.1 \mathrm{~Hz}), 5.57(\mathrm{~d}, 1 \mathrm{H}, J=5.1 \mathrm{~Hz}), 5.16(\mathrm{~d}, 1 \mathrm{H}, J=7.5 \mathrm{~Hz}), 4.43(\mathrm{t}$, $1 \mathrm{H}, J=4.7 \mathrm{~Hz}), 4.17(\mathrm{~m}, 3 \mathrm{H}), 4.07(\mathrm{t}, 1 \mathrm{H}, J=4.2 \mathrm{~Hz}), 3.90(\mathrm{~m}, 1 \mathrm{H}), 3.85(\mathrm{~m}, 1 \mathrm{H}), 3.69(\mathrm{t}, 1 \mathrm{H}, J=7.1$ $\mathrm{Hz}), 3.22\left(\mathrm{~d}, 1 \mathrm{H}, J=6.5 \mathrm{~Hz}\right.$, exchanged with $\left.\mathrm{D}_{2} \mathrm{O}\right), 2.13(\mathrm{~m}, 1 \mathrm{H}), 1.68(\mathrm{~m}, 1 \mathrm{H}), 1.60(\mathrm{~s}, 3 \mathrm{H}), 1.39(\mathrm{~s}$, 3H), $0.92(\mathrm{~s}, 9 \mathrm{H}), 0.91(\mathrm{~s}, 9 \mathrm{H}), 0.07(\mathrm{~s}, 3 \mathrm{H}), 0.06(\mathrm{~s}, 3 \mathrm{H}), 0.05(\mathrm{~s}, 3 \mathrm{H}), 0.04(\mathrm{~s}, 3 \mathrm{H}) ;{ }^{13} \mathrm{C} \mathrm{NMR}\left(\mathrm{CDCl}_{3}\right.$, 
$125 \mathrm{MHz}) \delta 163.2,150.4,142.6,134.4,131.4,129.4,127.9,111.5,102.3,92.4,88.2,86.7,76.2,74.3$, 72.6, 69.2, 66.6, 64.0, 38.4, 27.8, 26.1, 26.0, 25.7, 18.3, 18.2, -4.2, -4.4, -4.5, -4.6; MS (FAB) $m / z 792$ $\left(\mathrm{MH}^{+}\right)$; Exact MS (FAB) Calcd for $\mathrm{C}_{36} \mathrm{H}_{58} \mathrm{~N}_{5} \mathrm{O}_{9} \mathrm{SSi}_{2}:$ 792.3493, found: 792.3496 .

The physical data for $\mathbf{1 4}$ was in accordance with the compound obtained by reduction of $\mathbf{1 3 a}$.

Acetate 18. A mixture of $17(20 \mathrm{mg}, 25 \mu \mathrm{mol}), \mathrm{Ac}_{2} \mathrm{O}(2.8 \mu \mathrm{L}, 30 \mu \mathrm{mol}), \mathrm{Et}_{3} \mathrm{~N}(4.2 \mu \mathrm{L}, 30 \mu \mathrm{mol})$, and DMAP $(1 \mathrm{mg}, 7.5 \mu \mathrm{mol})$ in $\mathrm{CH}_{3} \mathrm{CN}(1 \mathrm{~mL})$ was stirred for $12 \mathrm{~h}$ at room temperature. After $\mathrm{MeOH}(1$ $\mathrm{mL}$ ) was added to the mixture, the mixture was evaporated under reduced pressure. The residue was partitioned between AcOEt $(30 \mathrm{~mL})$ and $\mathrm{H}_{2} \mathrm{O}(20 \mathrm{~mL})$, and the organic layer was washed with saturated aqueous $\mathrm{NaHCO}_{3}(20 \mathrm{~mL})$ and brine $(10 \mathrm{~mL})$, dried $\left(\mathrm{Na}_{2} \mathrm{SO}_{4}\right)$, and evaporated under reduced pressure. The residue was purified by flash column chromatography $\left(\mathrm{SiO}_{2}, 33 \% \mathrm{AcOEt} / \mathrm{hexane}\right)$ to give 18 (21 mg, quant. as a white foam): ${ }^{1} \mathrm{H} \mathrm{NMR}\left(\mathrm{CDCl}_{3}, 500 \mathrm{MHz}\right) \delta 8.49$ (br s, $1 \mathrm{H}$, exchanged with $\left.\mathrm{D}_{2} \mathrm{O}\right)$, $7.78(\mathrm{~d}, 1 \mathrm{H}, J=8.1 \mathrm{~Hz}), 7.54-7.27(\mathrm{~m}, 5 \mathrm{H}), 5.88(\mathrm{~d}, 1 \mathrm{H}, J=4.2 \mathrm{~Hz}), 5.74(\mathrm{dd}, 1 \mathrm{H}, J=1.1,8.1 \mathrm{~Hz})$, $5.27(\mathrm{ddd}, 1 \mathrm{H}, J=3.0,5.8,8.2 \mathrm{~Hz}), 5.07(\mathrm{~d}, 1 \mathrm{H}, J=7.4 \mathrm{~Hz}), 4.18(\mathrm{dd}, 1 \mathrm{H}, J=3.2,4.7 \mathrm{~Hz}), 4.15(\mathrm{t}, 1 \mathrm{H}$, $J=5.1 \mathrm{~Hz}), 4.13(\mathrm{t}, 1 \mathrm{H}, J=4.4 \mathrm{~Hz}), 4.04(\mathrm{~m}, 1 \mathrm{H}), 4.03(\mathrm{t}, 1 \mathrm{H}, J=4.3 \mathrm{~Hz}), 3.90(\mathrm{t}, 1 \mathrm{H}, J=4.5 \mathrm{~Hz})$, $3.67(\mathrm{t}, 1 \mathrm{H}, J=6.9 \mathrm{~Hz}), 2.17(\mathrm{ddd}, 1 \mathrm{H}, J=5.1,8.3,14.3 \mathrm{~Hz}), 2.10(\mathrm{~s} 3 \mathrm{H}), 2.04(\mathrm{ddd}, 1 \mathrm{H}, J=3.3,8.2$, $14.3 \mathrm{~Hz}), 1.55(\mathrm{~s}, 3 \mathrm{H}), 1.37(\mathrm{~s}, 3 \mathrm{H}), 0.88(\mathrm{~s}, 9 \mathrm{H}), 0.87(\mathrm{~s}, 9 \mathrm{H}), 0.09(\mathrm{~s}, 3 \mathrm{H}), 0.06(\mathrm{~s}, 3 \mathrm{H}), 0.05(\mathrm{~s}$, 3H),0.02 (s, 3H); ${ }^{13} \mathrm{C} \mathrm{NMR}\left(\mathrm{CDCl}_{3}, 125 \mathrm{MHz}\right) \delta 181.3,169.6,169.3,163.0,139.7,134.6,132.0,129.3$, $128.1,111.4,102.4,101.7,100.1,88.6,87.2,84.9,76.4,76.2,75.9,71.9,69.5,68.4,63.8,36.0,30.3$, 27.9, 26.0, 21.4, 20.9, -4.0, -4.2, -4.5, -4.8; MS (FAB) $m / z 883\left(\mathrm{MH}^{+}\right)$; Exact MS (FAB) Calcd for $\mathrm{C}_{38} \mathrm{H}_{60} \mathrm{~N}_{5} \mathrm{O}_{10} \mathrm{SSi}_{2}: 834.3599$, found: 834.3578.

Protected tunicaminyluracil 19. A mixture of $18(29 \mathrm{mg}, 34 \mu \mathrm{mol})$ and $\mathrm{PhSeH}(10 \mu \mathrm{L}, 101 \mu \mathrm{mol})$ in $\mathrm{Et}_{3} \mathrm{~N}(200 \mu \mathrm{L})$ was heated for $1 \mathrm{~h}$ at $60^{\circ} \mathrm{C}$. Additional $\mathrm{PhSeH}(21 \mu \mathrm{L}, 202 \mu \mathrm{mol})$ was added to the mixture, and the mixture was further stirred for $1 \mathrm{~h}$ to complete the reaction. The mixture was evaporated under reduced pressure. A mixture of the residue, phthalic chloride $(15 \mu \mathrm{L}, 101 \mu \mathrm{mol})$, and 
DBU $(32 \mu \mathrm{L}, 217 \mu \mathrm{mol})$ in toluene $(1 \mathrm{~mL})$ was heated for $3 \mathrm{~h}$ at $100{ }^{\circ} \mathrm{C}$. The mixture was allowed to cool to room temperature and evaporated under reduced pressure. The residue was partitioned between AcOEt $(20 \mathrm{~mL})$ and $\mathrm{H}_{2} \mathrm{O}(10 \mathrm{~mL})$, and the organic layer was washed with brine $(10 \mathrm{~mL})$, dried $\left(\mathrm{Na}_{2} \mathrm{SO}_{4}\right)$, and evaporated under reduced pressure. The residue was purified by column chromatography $\left(\mathrm{SiO}_{2}, 33 \% \mathrm{AcOEt} / \mathrm{hexane}\right)$ to give $19(31 \mathrm{mg}, 98 \%$ as a pale yellow foam $):{ }^{1} \mathrm{H} \mathrm{NMR}\left(\mathrm{CDCl}_{3}, 500\right.$ MHz) $\delta 8.04$ (br s, $1 \mathrm{H}$, exchanged with $\left.\mathrm{D}_{2} \mathrm{O}\right), 7.87-7.17(\mathrm{~m}, 10 \mathrm{H}), 5.92(\mathrm{~d}, 1 \mathrm{H}, J=4.8 \mathrm{~Hz}), 5.87(\mathrm{~d}$, $1 \mathrm{H}, J=10.3 \mathrm{~Hz}), 5.76(\mathrm{~d}, 1 \mathrm{H}, J=8.2 \mathrm{~Hz}), 5.27(\mathrm{ddd}, 1 \mathrm{H}, J=3.2,5.4,8.2 \mathrm{~Hz}), 4.95(\mathrm{dd}, 1 \mathrm{H}, J=6.9$, $10.3 \mathrm{~Hz}), 4.41(\mathrm{t}, 1 \mathrm{H}, J=10.4 \mathrm{~Hz}), 4.33(\mathrm{t}, 1 \mathrm{H}, J=7.3 \mathrm{~Hz}), 4.17(\mathrm{t}, 1 \mathrm{H}, J=3.8 \mathrm{~Hz}), 4.14(\mathrm{dd}, 1 \mathrm{H}, J=$ $4.5,8.1 \mathrm{~Hz}), 3.98(\mathrm{t}, 1 \mathrm{H}, J=4.6 \mathrm{~Hz}), 3.93(\mathrm{t}, 1 \mathrm{H}, J=4.1 \mathrm{~Hz}), 2.22(\mathrm{ddd}, 1 \mathrm{H}, J=4.4,8.0,14.1 \mathrm{~Hz})$, $2.15(\mathrm{~s}, 3 \mathrm{H}), 2.11(\mathrm{ddd}, 1 \mathrm{H}, J=5.5,8.9,14.1 \mathrm{~Hz}), 1.50(\mathrm{~s}, 3 \mathrm{H}), 1.32(\mathrm{~s}, 3 \mathrm{H}), 0.89(\mathrm{~s}, 9 \mathrm{H}), 0.88(\mathrm{~s}, 9 \mathrm{H})$, 0.07 (s, 3H), $0.06(\mathrm{~s}, 3 \mathrm{H}), 0.05(\mathrm{~s}, 3 \mathrm{H}), 0.03(\mathrm{~s}, 3 \mathrm{H}) ;{ }^{13} \mathrm{C} \mathrm{NMR}\left(\mathrm{CDCl}_{3}, 125 \mathrm{MHz}\right) \delta$ 169.5, 167.8, 162.6, $150.0,139.5,134.3,131.7,131.1,128.9,127.3,132.6,111.6,102.4,88.0,85.2,83.8,75.7,72.8,72.0$, $69.4,68.8,53.3,36.0,27.5,25.8,25.7,21.2,18.0,17.9,-4.3,-4.5,-4.7,-4.9 ;$ MS (FAB) $m / z 938$ $\left(\mathrm{MH}^{+}\right)$; Exact MS (FAB) Calcd for $\mathrm{C}_{46} \mathrm{H}_{64} \mathrm{~N}_{3} \mathrm{O}_{12} \mathrm{SSi}_{2}$ : 938.3749, found: 938.3724 .

\section{References}

(1) Isolation: a) Takatsuka, A.; Arima, K.; Tamura, G. J. Antibiot. 1971, 24, 215. b) Takatsuka, A.; Tamura, G. J. Antibiot. 1971, 24, 224. c) Takatsuka, A.; Tamura, G. J. Antibiot. 1971, 24, 232. d) Takatsuka, A.; Tamura, G. J. Antibiot. 1971, 24, 285.

(2) Structure elucidation: a) Ito, T.; Kodama, Y.; Kawamura, K.; Suzuki, K.; Takatsuki, A.; Tamura, G. Agric. Biol. Chem. 1977, 41, 2303. b) Takatsuki, A.; Kawamura, K.; Okina, M.; Kodama, Y.; Ito, T.; Tamura, G. Agric. Biol. Chem. 1977, 41, 2307. c) Ito, T.; Takatsuki, A.; Kawamura, K.; Saito, K.; Tamura, G. Agric. Biol. Chem. 1980, 44, 695.

(3) Biosynthesis: Tsvetanova, B. C.; Kiemle, D. J.; Price, N. P. J. J. Biol. Chem. 2002, 277, 35289. 
(4) Tamura, G. Tunicamycin; Japan Scientific Press: Tokyo, 1982.

(5) Schwartz, R. T.; Datema, R. Trends Biochem. Sci. 1980, 65. Elbein, A. D. Trends Biochem. Sci. 1981, 219. Morin, M. J.; Bernacki, R. J. Cancer Res. 1983, 43, 1669.

(6) Wan, R.; Steensma, D. H.; Takaoka, Y.; Yun, J. W.; Kajimoto, T.; Wong, C.-H. Bioorg. Med. Chem. 1997, 5, 661. Silva, D. J.; Sofia, M. J. Tetrahedron Lett. 2000, 41, 855.

(7) For a recent review associated with glycosyltransferase inhibitors: Compain, P.; Martin, O. R. Bioorg. Med. Chem. 2000, 9, 3077.

(8) a) Suami, T.; Sasai, H.; Matsuno, K.; Suzuki, N. Carbohydr. Res. 1985, 143, 85. b) Suami, T.; Sasai, H.; Matsuno, K.; Suzuki, N.; Fukuda, Y.; Sakanaka, O. Tetrahedron Lett. 1984, 25, 1984.

(9) a) Myers, A. G.; Gin, D. Y.; Rogers, D. H. J. Am. Chem. Soc. 1994, 116, 4687. b) Myers, A. G.; Gin, D. Y.; Rogers, D. H. J. Am. Chem. Soc. 1993, 115, 9661.

(10) Wittig reaction: Secrist III, J. A.; Wu, S. R. J. Org. Chem. 1979, 44, 1434. Karpiesiuk, W.; Banaszek, A. Tetrahedron 1994, 50, 2965. [4+2] cycloaddition: Danishefsky, S. J.; DeNinno, S. L.; Chen, S.-H.; Boisvert, L.; Barbachyn, M. J. Am. Chem. Soc. 1989, 111, 5810. Danishefsky, S. J.; Barbachyn, M. J. Am. Chem. Soc. 1985, 107, 7761. Wadsworth-Horner-Emmons condensation: Ramza, J.; Zamojski, A. Tetrahedron 1992, 48, 6123. Insertion or addition of diazo-sugar: SarabiaGarcia, F.; Lopez-Herrera, F. J.; Gonzalez, M. S. P. Tetrahedron 1995, 51, 5491.

(11) a) Ichikawa, S.; Shuto, S.; Minakawa, N.; Matsuda, A. J. Org. Chem. 1997, 62, 1368. b) Kodama, T.; Shuto, S.; Ichikawa, S.; Matsuda, A. J. Org. Chem. 2002, 67, 7706.

(12) Ichikawa, S.; Shuto, S.; Matsuda, A. Tetrahedron Lett. 1998, 39, 4525.

(13) Ichikawa, S.; Shuto, S.; Matsuda, A. J. Am. Chem. Soc. 1999, 121, 10270.

(14) Lemieux, R. U.; Ratcliffe, R. M. Can.J. Chem. 1979, 57, 1244.

(15) The uridine 5'-aldehyde derivative 12 was prepared by Dess-Martin periodinane oxidation of 2',3'-di- $O$-TBS uridine. 
(16) Comprehensive Organic Synthesis. Pergamon Press, 1991, 7, 193-217. A review for intramolecular Pummerer reaction: Padwa, A.; Gunn, D. E.; Osterhout, M. H. Synthesis 1997, 1353. 